Book Review

\title{
An Introduction to Islam
}

\author{
David Waines. Cambridge, UK: Cambridge University \\ Press, 1995, pp. 332.
}

David Waines, Islamic lecturer at Lancaster University, divides $A n$ Introduction to Islam into three parts. Part 1 deals with the Qur'an and the Sunnah in the formative period, and part 2 is devoted to Islamic teachings and practices, including separate chapters on Islamic law, theology, Sufism, and Shi'ism. The connecting thread in these first two parts is the ways in which Muslim scholars have explored "revelation and the experience of their Prophet, Muhammad" (p. 3). Part 3 treats Islam in the modem world, recounting the period over the last two centuries during which Muslims have been challenged by western hegemony and have sought to establish a modern sense of Islamic identity.

This is a comprehensive, wide-ranging, and up-to-date treatment of Islamic history and culture. It is by no means the only recent introduction on Islam by a westem scholar: Victor Danner's The Islamic Tradition: An Introduction (1988) deals with the Islamic intellectual and spiritual tradition within the context of other religious traditions. Frederick M. Denny's An Introduction to Islam (1985) offers a comprehensive, simple account of Islam, and Annemarie Schimmels' Islam: An Introduction is a concise and 
readable account of the cultural history of Islam. Like these excellent introductions for the general reader, David Waines also seeks to present Islam and Muslims "as Muslims might recognise them, rather than as others have described them" (p. 3). Although he uses the Arabic in his use of "he" for God, the author does not write from a believer's perspective.

An Introduction to Islam is noteworthy for its creative style and scholarly approach. The author has sought to make it readable, informative, and objective. As an objective scholarly work, he employs the academic, phenomenological, and historical approaches to the study of Islam. He presents Islam within an historical context, without being too reductionistic, and maintains a detached objectivity throughout. This is clearly noticeable in the fact that he presents information in a balanced manner and does not reveal his bias toward a particular point of view. An account of historical conditions are given as a partial explanation for conversion to Islam in the fact that Arabs were more attached to idols out of convenience than out of conviction.

The gods were consulted on various matters of domestic and other concerns ... Y Yet as much as advice was sought, it was not always accepted with good grace ... Another petitioner offered a sacrifice to an idol ... hoping that punishment would befall a tribesman who had violated the idols' sanctity. When nothing happened, the petitioner renounced all idols and embraced Christianity. When he heard Muhammad preach his message, he converted to Islam. (pp. 9-10)

His critical approach is well illustrated in his treatment of consensus $\left(i j m \bar{a}^{*}\right)$ as a source of law. Verse 4:115 is cited to support $i j m \bar{a}^{*}$, but some scholars are not convinced that it was meant to refer to this practice. The hadith "My community shall never agree on an error" is also used to support consensus. However, the author pints out that this hadith is not reliable.

The author presents factual information in a balanced way and assesses it in an unbiased manner. Al Ghazāli condemned philosophers for denying God's power because of their denial of bodily resurrection after death and the physical reality of paradise and hell. His judgment was "partially fair," according to the author, as philosophers did not deny the scriptures as such but only viewed them differently. Furthermore, al Ghazāli himself admits that the masses can only understand things literally (pp. 126-28).

I am also impressed by the author's impartial judgment of two conflicting claims between Islamic thinkers who insist on the state and secular critics who dismiss it as "hopelessly utopian." The judgment is valid if radical blueprint of the Islamic state is assumed to be thoroughly utopian in nature. On the other hand, if the radical groups' proposals envisage adequate institutional checks on the power and behavior of the ruler by means of a consultative body responsible to the community, there is a possibility that a "theo-democracy" could function in practice. (p. 246). 
In chapter 4, Islamic theology is placed in its historical context, its key figures are introduced, and its origins identified. Waines states that the Khärijite questions concerning who is a Muslim did not emerge in the cloister but rather in the "traumatic aftermath of communal conflict" (p. 104). $\mathrm{He}$ also traces the historical significance of the Mu'tazilites for today, as their general attitudes have "reemerged in the guise of Islamic modernism" (p. 115). Chapter 5 introduces Sufism in a very novel way with a "Muslim Robinson Crusoe" in Ibn Țufayl's Hayy ibn Yaqzān. This twelfth-century philosophical tale brings out the potentiality of the human spirit.

Part 3, "Islam in the Modern World," opens with Ibn Battūtah, who begins his journey from Morocco to Makkah in 1325. Through his eyes, a geographical account of Anatolia, Maldives, Sumatra, and China is given. "Empires of the Sultans" takes us beyond his time and provides a brief comparison of the Ottomans, Moghuls, and Safavids and then touches on themes of Islamic jurisprudence and Sufism. The discussion of mosques includes a brief description of Islamic architecture. The final section deals with two prominent Muslims of the eighteenth century, Shāh Wāli Allāh and Muhammad ibn 'Abd al Wahhāb, and the role of ijtihad.

This creative technique of using a traveler is used to introduce contemporary Islam. Our interest is drawn to another Moroccan traveler, Muhammad al Șaffär, who went to Paris in 1846. Although impressed with their technology, he said that its inhabitants are "driven by the demands of commerce rather than guided by the norms of religion." He returned home, happily, where "the daily routine was measured by the ritual of prayer rather than by the ticking of a banker's clock" (p. 213). Although Ibn Battutah observed a variety of cultures among the community of Muslims throughout the world, they were all united by their one faith.

Unlike Ibn Battutah, who was conscious of belonging to the ummah, the late nineteenth- and twentieth-century feeling of universal fellowship was under serious threat. Muslim reformers, such as Ahmad Khan and Muhammad 'Abdu, while sympathetic to the developments in parts of the ummah, responded in the first instance to the realities confronting their immediate communities (p. 221). The author also deals with the Muslim Brotherhood in Egypt, the Islamic Association of Mawdudi in Pakistan, and the rise of Khomeini in Iran.

Chapter 6 covers the historical development of Shi'ism, starting with the Prophet Muhammad and 'Alì ibn Abū Țālib. Present-day customs, such as the commemoration of Husayn's martyrdom, is explained in terms of the Karbalā' incident. The author's style succeeds in capturing the sorrowful mood of the Shi'ah and, at the same time, distinguishes between historical events and legends (p. 159 ff.). His comparative treatment of Shi'ism will help Sunni readers to understand Shi'ism in relation to Sunni belief.

On the Rushdi Affair, the author identifies four historical factors to explain why the Muslims of Bradford (UK) reacted to The Satanic Verses. The fist is Khomeini's fatwa; second, the misunderstanding between the dominant liberal culture in Britain and the Muslim minority; third, the 
Bradford Muslims who come from the Punjab brought to Britain a tradition of veneration for the Prophet; and fourth, the community's frustration in adjusting to the impact of British culture (p. 261).

The author traces the Nation of Islam, which began as an "idiosyncratic" theory under the leadership of Elijah Muhammad, to its transformation into "normative" Islam under the leadership of Wallace D. Muhammad, to the splinter group of Minister Louis Farrakhan, who continues to expound the original teachings of Elijah Muhammad's Nation "as more relevant to the true condition of the majority of America's black population" (p. 263).

Western scholars have recently shown great interest in the problems concerning the origins of Islam, mainly the Qur'an and the hadith. Their view on Islamic origins are covered in the last chapter with citations form their works. On Sufis, the author traces two Sufi brotherhoods: the Chisfiyah in India and the Shādhiliyah in North Africa. He outlines their distinguishable features and mentions al Ghazālı and some of his works but, unfortunately, does not mention his historical role in reforming Sufism.

The notes for each chapter are kept to a minimum and are used to indicate the sources of quotations in the text from English translations of classical Muslim sourses. The books for further reading are in English, are useful to the researcher, and are described briefly. A glossary of Arabic terms and an index are included. The book is enhanced by seven photographs of persons from different countries, ten pictures of mosques, and four plates of calligraphy from the Qur'an.

The author has succeeded in demonstrating that the Qur'an is the "bedrock of practically every aspect of Islamic religious culture." His book is valuable for its readability, insights, and objectivity. Waines is to be congratulated for a fine and patient piece of creative, scholarly writing on Islam.

Yasien Mohamed Department of Arabic Studies University of the Western Cape Bellville, South Africa 